\title{
INFORMATION MANAGEMENT MODEL IN THE MANUFACTURING COMPANY
}

\author{
Małgorzata Łęgowik-Małolepsza \\ Czestochowa University of Technology, Poland
}

\begin{abstract}
The paper is to explore the possibilities of applying the modern information management model in the manufacturing company. In the theoretical part of the paper, there has been discussed the problem associated with the essence of information management in the enterprise. In the subsequent part of the paper, there has been discussed the cycle of information management and there has been presented information management in the perspective of static and dynamic approach, paying attention to the goals of information management in the enterprise. In the empirical part of the paper, using descriptive analysis, there has been presented the case study of the application of the ASTEX model for restructuring of the organization of administrative and office work in the surveyed manufacturing company. There has been indicated the impact of the application of the modern information management tool in the company on the efficiency of the organization of administrative and office work.
\end{abstract}

Keywords: information management, cycle of information management, basic levels of information management

DOI: $10.17512 /$ znpcz.2016.1.17

\section{Introduction}

The development of information management is closely related to changing conditions in which enterprises operate. On account of the complexity of the environment, it is necessary to currently adapt to new conditions. The strategic importance of the role of information in the implementation of the assumed economic processes is the reason for an increase in the significance of information management in the enterprise. The aim of the paper is to explore the possibilities of the application of the modern information management model in the manufacturing company.

\section{The essence of information management}

Information is of the key importance in the process of making a decision and monitoring its implementation. Taking into account the reduction in uncertainty of an operation, entrepreneurs use opportunities to rapidly and easily gather, process and transfer information. The integrated information as a non-material labor tool reduces the risk (Skowron-Grabowska 2006, pp. 142-149; 2014, pp. 35-39) associated with the activity of the enterprise on the market. The functioning of enterprises in the complex information environment, characterized by dynamic 
development of technologies and information processes, requires the creation of appropriate structures, systems and procedures of information management. R. Zygała states that "information management is conscious behavior of people aimed at optimizing the role of information while achieving goals of the organization" (Zygała 2007, pp. 46-56). The author mentioned above presents the approaches to information management of the authors such as: T. Davenport, C. W. Choo or J. Kirk, who perceive information management as the process consisting of the following stages, creating the cycle of information management (Zygała 2007, pp. 46-56; Choo 1998):

- identification of information needs - information management cycle begins with adaptive behavior when, in the enterprise or its environment, something new is happening. As a result of this event, there occurs a new need for information to satisfy, necessary to take decisions relevant for the existing situation.

- acquisition of information - this stage consists in planning sources and acquiring information from these sources in response to arising information needs,

- organization and storage of information - at this stage there takes place systemizing and gathering of useful information applied in the framework of the specific enterprise,

- development of information products and services - products and services can develop through acquiring new information, which takes place due to an increase in the quality of information and its adjustment to users' requirements,

- distribution of information - distribution is aimed at sharing information between users who need it,

- use of information - information is used in the situation of creating and using knowledge, interpretation of information, problem solving and decisionmaking.

The presented cycle of information management is graphically shown in figure 1.

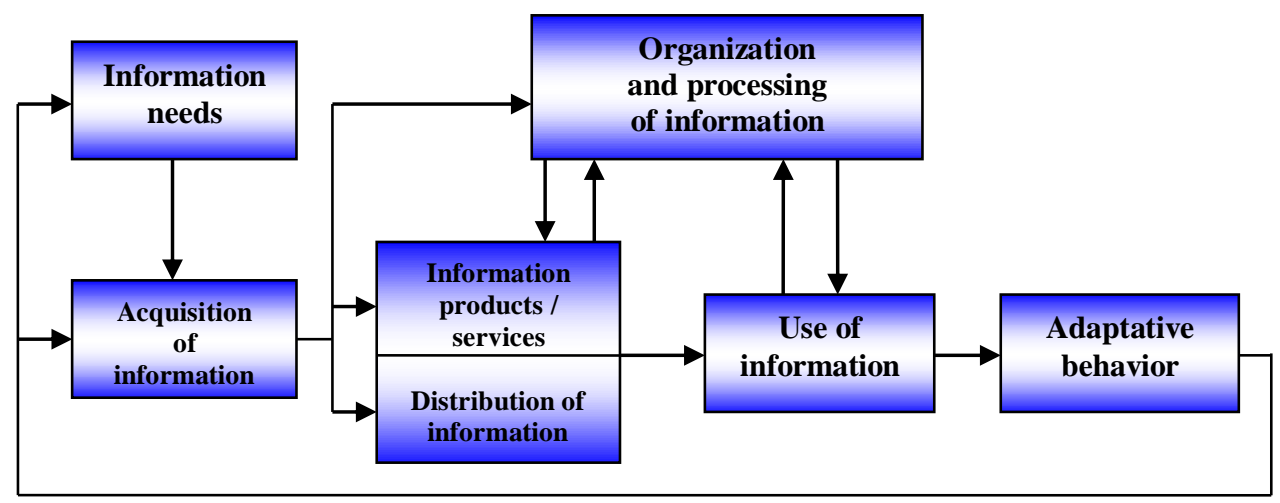

Figure 1. Information management cycle

Source: Zygała 2007, pp. 46-56; Choo 1998. 
Actually, the cycle does not need to include all the listed elements since they may interlink, cumulate or isolate completely new elements. The discussed process constitutes a general view on the functioning of the cycle of information management in the enterprise.

According to L. Kieltyka, "information management must be considered as the process which is to guarantee confidentiality, integrity, accountability and credibility of the processed information" (Kieltyka 2001, pp. 204-205). The author believes that the system of information management should comply with the model of the general management and operation of the enterprise, with its strategic goals and internal organization. Moreover, it should be adjusted to the size of the enterprise, its maintenance ought not to be complicated, it should currently update databases and use the source which business intelligence is. It is important for the system of information management to be adjusted to the needs of all its users, simultaneously securing data against their use by unauthorized people. The model of information management, taking into account the general model of management has been developed by L. Kieltyka (see figure 2). In the figure, there are included the exemplary systems of information management.

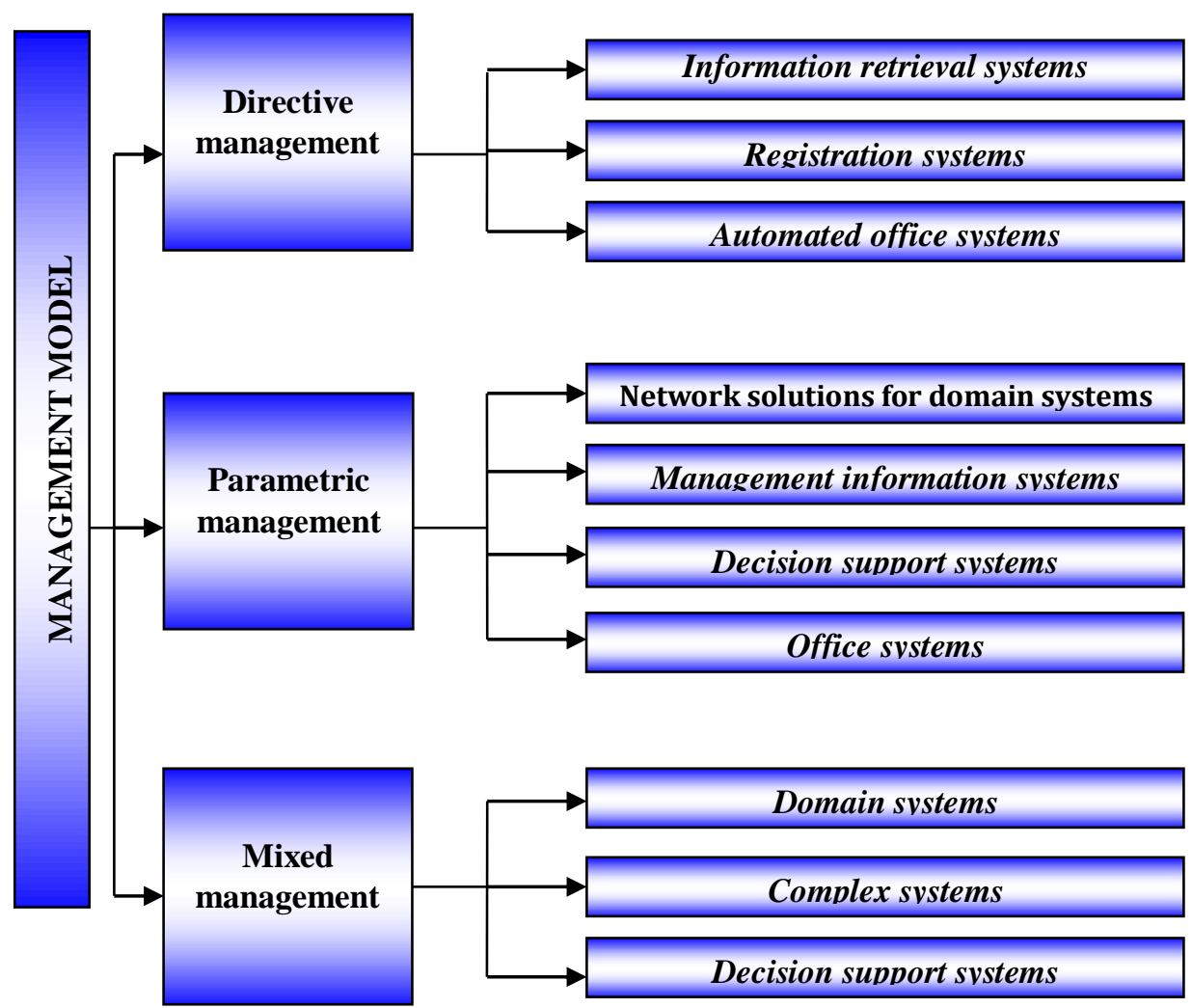

Figure 2. Information management model according to step 2 of the circuit topology

Source: Zygała 2007, pp. 46-56; Choo 1998. 
On the basis of the available subject literature, there are identified: operational, tactical and strategic levels of management. At each of these levels, there are the issues associated with information management that may be considered both in the perspective of static and dynamic approach.

The static approach to information management refers to the management of information resources (Kościelniak 2010, pp. 91-98; Kościelniak 2014, pp. 65-72) and "is associated with the issues of information policy, the required level of the quality of information in the context of information technologies" (Egeman 2002, pp. 146-148). In the perspective of this approach, management refers only to information itself. In the perspective of the dynamic approach, information management consists in management of information processes and "is associated with (...) planning, organizing and supervising and monitoring the actual implementation of sequences of actions contributing to information processes and technologies used in them" (Egeman 2002, pp. 146-148).

Similarly to three basic levels of management mentioned above, also information management is considered from the perspective of the same three levels (Egeman 2002, pp. 146-148):

- strategic management of information - consists in determining what the resources, processes and information technologies of the enterprise are to be like within 2-3 years. It is also planned how to use information to improve the market position of the enterprise and achieve competitive advantage.

- tactical management of information - including management of technologies, processes and information resources in the period of up to one year. In the framework of this management the following are significant: responding to changes in the environment, medium-term supervision of the flows of streams of information and the functioning of information system.

- operational management of information - consists in current planning, organizing, developing and monitoring the functioning of the information system, access to information and using it in everyday work.

While discussing the issues associated with the essence of information management (Łęgowik-Świącik 2014, pp. 308-31), the attention should be drawn to the goals of information management in the enterprise, which are considered with reference to the following three areas: enterprise resources, functions and management problems (Zygała 2007, pp. 46-56).

In the area of enterprise resources, information management ought to support the processes associated with the management of all enterprise resources, thus, human resources, beginning with recruitment, through motivation, and ending with dismissal. Another resource is finance management, among others, including supporting the flows of financial streams. Subsequently, information management is to support the processes associated with the management of fixed and current assets, their purchase and use, and involvement in the production process. Finally, information management is aimed at supporting and facilitating information flows and, consequently, powering the enterprise and its employees with knowledge. Therefore, information management is to support knowledge and information management in the whole chain of creating the enterprise value, by supplying information in the right amount and quality. 
From the point of view of enterprise functions, information management refers to functional areas which occur in the enterprise. It is to support the processes, among others, associated with the area of supply management. It is to improve the flow of information on suppliers, supplies, times of deliveries etc. Another functional area is production management where appropriate information management is to facilitate the planning and monitoring of the production process. Providing information in the right amount and quality is also essential for the functioning of other areas, e.g. management of distribution and marketing. To achieve the company goals, the up-to-date information referring to the research on markets, tastes and preferences of current and possible customers, promotion and advertising, is necessary.

Management problems are the area in which information management is to serve the current monitoring of performance management. It is to supply information for calculating performance indicators and, in the case of obtaining improper levels of these indicators, to indicate the areas bringing about distortion. Similarly to performance management, information management is to serve quality management. It is to currently control the level of quality in all possible areas and justify the reasons for shortages in the quality if such cases occur.

The presented part of the paper describing the essence of information management in the enterprise indicates that information management, through its presence in the activity of the enterprise and the achievement of own goals, is to help solve decision-making problems. Taking decisions in the turbulent environment requires the most complete information about the environment. In the absence of access to information, managers must analyze markets, competitors and their own companies (Otola 2013, p. 143.). The pace of decision-making is determined by the rapidity of collecting information and the time of its processing to define the decision-making problem and to evaluate its results (UrbanowskaSojkin 2011, p. 19; Kowalska S., 2012, p. 83; Stępień 2012, p. 359). This means that information is a set of processed data which are generated in the specific form and passed for a particular purpose. The task of information management is knowledge management in the enterprise and also the improvement of information processes. To depict the essence of information management, in the subsequent part of the paper, there has been presented the case study depicting the ASTEX model as the method of improving information processes in the manufacturing company

\section{The verification of the ASTEX model in the management of the manufacturing company - the case study}

One of the methods of information management is the ASTEX model, which is used to improve information processes. It was developed on the basis of the research carried out in the years of 1982-1986 at the BMW concern in Munich. The objective of the ASTEX model is the analysis of the barriers to labor efficiency resulting from the existing division of labor and the level of employees' education. ASTEX is the model used for restructuring of the organization of 
administrative and office work, and its full name means: "the method of forming the structure of work in the development and processing of textual information and the associated control areas in the industrial company" (Potocki 1998, p. 141). The ASTEX model was used in the surveyed company to systematize the organization of administrative and office work.

The empirical studies were conducted on the basis of the descriptive analysis of the information obtained from the company engaged in production activity. In the analyzed company, the ASTEX model was applied as the method of information management. The basis for the use of the model was information processes.

The implementation of the ASTEX model in the surveyed company took place in five stages. The first stage was determining the ranges and factors of organizational, staff and technical changes - this stage consisted in conducting the general analysis of the functioning of the enterprise organizational cells with reference to three main areas, such as: functions, qualifications, technology. The aim of this activity was to indicate the areas, cells and human resources in which it is essential to make relevant changes and eliminate shortages in the field of instrumentalization. The second stage was registering the previous condition the stage began with the development of the function tree recording the implementation of current functions, tasks, qualifications and technical equipment of each organizational cell. At the subsequent stage of this process, there were considered in detail individual positions in the indicated cells, taking into account basic courses of work (all procedures, processes) performed at these positions, support activities and communication links between them. For the combined listing of the listed properties there was used the synoptic table in the framework of which there was included the percentage share of independent, auxiliary and support work.

The third stage was the assessment of the existing condition and recognizing the possibility of the participation of auxiliary workers in the participatory model - with reference to the performed functions, there was made the division of the current division of labor, employment structure and employees' qualifications. The second part of the third stage was exploring the possibilities of the participation of auxiliary workers in the participatory model, the basis of which was the total score of the analyses of the existing condition. There were determined two options of restructuring: division of labor and qualifications of employees. The restructuring of the division of labor was analyzed from the perspective of two approaches. Firstly, efficiency-based approach to restructuring of work - there were identified unnecessary tasks and activities and they were eliminated while aiming at cost reduction. Secondly, humanization-based approach - implemented by diversifying and enriching the work of mainly auxiliary workers. The restructuring of employees' qualifications referred to an increase in qualifications, skills and education of employees. The general idea of restructuring consisted in the fact that there were analyzed the suggestions for transferring some of duties and tasks performed by independent employees to auxiliary workers in the course of developing the existing or acquiring new broadly understood qualifications of auxiliary workers. To assess the options of 
restructuring there was used the decision table comparing advantages and disadvantages of the existing work organization in relation to the suggestions resulting from the participatory model.

The fourth stage was designing a new organization based on the participatory model - at the fourth stage there was the division of labor into tasks which were to be performed under the specific organizational cell in the participatory model, with their division into independent, auxiliary and participatory workers. On the basis of new work organization, there was determined the specific consequence of the implementation of the work process by individual employees. During the stage IV, in the course of designing the options of new work organization, there were assessed the costs of the implementation of the specific solution. This constituted one of the bases for the selection of the optimal option, which the discussed stage ended with. Another stage was preparing employees for work in the participatory model - contrary to appearances, the analyzed stage was particularly important and complex, since there took place the transfer of all assumptions of the method to employees and the success of the whole project was dependent on understanding and subjecting to the new structure of work by them. Therefore, the idea of this stage was to familiarize workers with new work organization through organizing training of different proficiency levels and dependent on the occupied position. The people performing the function of participatory workers were subjected to the specific training serving the identification of the point of interlinking of tasks or determining the limits of powers related to positions.

At the last stage, there was the implementation of new work organization - the participation of employees in thorough training was followed by the implementation of new work organization. The involvement of employees and motivating them was very important. The implemented solution was assessed from the point of view of functionality and with reference to the basic solution. The attention was drawn to the humanization of work and the needs which had not been satisfied previously (Czekaj 1993, pp. 45-48).

The ASTEX model is a modern and detailed method serving restructuring of the division of labor, employees' qualifications and technology. The advantage of the model is the fact that it combines three areas. It refers to organizational and administrative progress, improves qualifications and brings about development of employees and is based on modern technological solutions. Additionally, it contributes to humanization of the division of labor, brings about a greater sense of self-development to employees. The model focuses on the identification of the areas designed for improvement and the modes of its implementation. The introduction of the participatory model of work organization is an interesting solution which brings about a lot of opportunities for development of employees.

\section{Conclusions}

The aim of the paper has been to explore the possibilities of the application of the modern information management model in the manufacturing company. In the paper, using descriptive analysis, there has been presented the case study of the 
application of the ASTEX model, which was used for restructuring of the organization of administrative and office work in the surveyed manufacturing company. The basis for the model application was information processes which take place in the surveyed company. The use of the ASTEX model in the analyzed company indicates high usability of the tool as the information management method in the enterprise.

\section{References}

1. Choo C. W., Information Management for the Intelligent Organization: The Art of Scanning the Environment, ASIS, Medford, 1998.

2. Czekaj J., Metoda ASTEX, [in:] Nowoczesne metody usprawniania procesów informacyjnych $w$ organizacjach gospodarczych $i$ administracyjnych, collective work, ed. Z. Martyniak, Akademia Ekonomiczna w Krakowie, Kraków, 1993, pp. 45-48.

3. Egeman H., Istota zarzadzania informacja, [in:] Wstęp do informatyki gospodarczej, collective work, ed. A. Rokicka-Broniatowska, Wydanie drugie zmienione, Szkoła Główna Handlowa [in:] Warszawie, Oficyna Wydawnicza, Warszawa, 2002, pp. 146-148.

4. Kiełtyka L., Model strategii zarzadzania informacja $w$ organizacji, [in:] Zarzadzanie zasobami informacji w przedsiębiorstwie. Ku przedsiębiorstwu przyszłości, collective work, eds. R. Borowiecki, M. Kwieciński, Wydawnictwa Naukowo-Techniczne, Warszawa, 2001, pp. 204-205.

5. Kościelniak H., An Improvement of Information Processes in Enterprises - the Analysis of Sales Profitability in the Manufacturing Company Using ERP Systems, Polish Journal of Management Studies, 2014, Vol.10, pp. 65-72.

6. Kościelniak H., Information Resources for Financial Monitoring in Enterprises, [in:] Economic Analysis, Vol. 43, 2010, pp. 91-98.

7. Kowalska S., Rola informacji $i$ jej bezpieczeństwo $w$ zarzadzaniu przedsiębiorstwem, [in:] Zarzadzanie informacja $i$ komunikacja $w$ organizacjach gospodarczych $i$ instytucjach sektora publicznego, eds. R. Borowiecki, J. Czekaj, TNOiK, Warszawa 2012, p. 83.

8. Łęgowik-Świącik S., Decision-Making in Enterprises from the Perspective of Information Technology, [in:] Current Problems of Maintenance of Electrical Equipment and Management, Technicka Univerzita v Kosiciach, Kosice 2014, pp. 308-31.

9. Otola I., Procesy zarzadzania przedsiębiorstwami a konkurencyjność $w$ warunkach zarażonego rynku. Wyd. PCz, Czestochowa 2013, p. 143.

10. Potocki A., Metoda ASTEX, [in:] Nowe metody organizacji i zarzadzania, ed. Z. Martyniak, Wydawnictwo Akademii Ekonomicznej w Krakowie, Kraków, 1998, p. 141.

11. Skowron-Grabowska B., Business Models in Transport Services. Przegląd Organizacji, 2014, nr 1, pp. 35-39.

12. Skowron-Grabowska B., Ryzyko i uwarunkowania działalności innowacyjnej w przedsiębiorstwach, [in:] Zarządzanie ryzykiem $w$ działalności gospodarczej, ed. E. Sitek, Cz. II, 2006, pp. 142-149.

13. Stępień M., Klasyfikacja i pomiar wybranych kategorii ekonomicznych $w$ aspekcie prawa bilansowego i podatkowego, Prace Naukowe UE we Wrocławiu, Wrocław 2012, p. 359.

14. Urbanowska-Sojkin E., Podstawy wyborów strategicznych $w$ przedsiębiorstwie. PWE, Warszawa 2011, p. 19.

15. Zygała R., Podstawy zarządzania informacja w przedsiębiorstwie, Wydawnictwo Akademii Ekonomicznej im. Oskara Langego we Wrocławiu, Wrocław, 2007, pp. 46-56. 
MODEL ZARZĄDZANIA INFORMACJĄ W PRZEDSIĘBIORSTWIE PRODUKCYJNYM

Streszczenie: Referat ma na celu poznanie możliwości zastosowania nowoczesnego modelu zarządzania informacją $\mathrm{w}$ przedsiębiorstwie produkcyjnym. W części teoretycznej referatu przybliżono tematykę związaną $\mathrm{z}$ istotą zarządzania informacją $\mathrm{w}$ przedsiębiorstwie. W dalszej części referatu omówiono cykl zarządzania informacją oraz przedstawiono zarządzanie informacją w ujęciu statycznym i dynamicznym, zwracając uwaga na cele zarządzania informacją w przedsiębiorstwie. W części empirycznej referatu, za pomocą analizy opisowej, zaprezentowano studium przypadku zastosowania modelu ASTEX do restrukturyzacji organizacji prac administracyjno-biurowych w badanym przedsiębiorstwie produkcyjnym. Wykazano wpływ zastosowania nowoczesnego narzędzia zarządzania informacjami w przedsiębiorstwie na efektywność organizacji prac administracyjno-biurowych.

Słowa kluczowe: zarządzanie informacją, cykl zarządzania informacją, podstawowe poziomy zarządzania informacją 